\title{
Bacterial growth on the marine sponge Halichondria panicea induced by reduced waterflow rate ${ }^{*}$
}

\author{
Herman Hummel, Antonie B. J. Sepers ${ }^{*}$, Lein de Wolf, Frans W. Melissen \\ Delta Institute ior Hydrobiological Research, Vierstraat 28, 4401 EA Yerseke, The Netherlands
}

\begin{abstract}
Mass mortalities of marine sponges and their large and varied associated fauna occur regularly, but the etiology of sponge diseases is poorly understood. We investigated causes of bacterial infections and subsequent mortality of the marine crumb-of-bread sponge Halichondria panicea. Besides a relationship with temperature, a strong influence of water-flow rates on bacterial infections and sponge mortality was found. Reduced water-flow rate promoted bacterial growth on the sponge. The infecting bacteria were identified as Alcaligenes faecalis and Acinetobacter calcoaceticus subsp. anitratis.
\end{abstract}

\section{INTRODUCTION}

The cosmopolitan and often abundant marine crumb-of-bread sponge Halichondria panicea (Pallas, 1766) forms a complete microhabitat with its associated fauna (Arndt 1928, Peattie \& Hoare 1981, Richter 1985). The associated organisms are commensals which at high water-flow rates stay in or near the sponge (mainly invertebrates and some vertebrates), and symbionts (mainly bacteria) living in the sponge with a mutual use of metabolic products.

Mass mortalities of sponges, which occur regularly, will have a strong impact on the large and varied associated fauna (reviewed by Lauckner 1980). According to Lauckner, mortalities of sponges were mostly ascribed to bacterial and fungal infections; however, the etiology of sponge diseases is hardly investigated and far from being understood. During experiments on the effects of tidal management by means of the new storm-surge barrier in the Oosterschelde estuary (Smies \& Huiskes 1981) a lethal effect of stagnant water on sponges was observed. This paper shows the effects of a water-flow rate reduction on bacterial growth and mortality of sponges. The infecting bacteria were identified.

- Communication No. 390 of the Delta Institute

- Present address: Research Institute for Nature Management, PO Box 9201, 6800 HB Arnhem, The Netherlands

\section{METHODS}

Sponges Halichondria panicea were collected in the Oosterschelde estuary near Yerseke (The Netherlands) at Mean Low Water Level. Encrusting specimens (1 to $2 \mathrm{~cm}$ thick) were sampled from stones. The sponges were transported to the laboratory within half an hour and placed in small containers of volume $1 \mathrm{l}$. The containers were connected to a seawater reservoir of $500 \mathrm{l}$; the seawater flowed through sets of 6 containers at different rates ranging from 1 to $1300 \mathrm{ml} \mathrm{min}^{-1}$. Different flow rates were achieved by a variation of the diameter of the water inlet into the containers. The inflow of water caused a turbulent flow of approximately 0 to $5 \mathrm{~cm} \mathrm{~s}^{-1}$. The normal maximum tidal flow rate near Yerseke is $100 \mathrm{~cm} \mathrm{~s}^{-1}$.

The sponges were submerged in sets of 6 containers. The experiments were repeated 9 times throughout the year from October 1984 to October 1985. Each time 2 different temperatures were chosen, ranging from -2 to $26{ }^{\circ} \mathrm{C}$. The temperature was controlled within a range of $\pm 1^{\circ} \mathrm{C}$. Color changes in the sponges were followed during the experiments. Color was determined by means of the Munsell Soil Color Cards ${ }^{\circledR}$. All colors of sponge and bacteria could be coded by cards of the $2.5 \mathrm{Y}, 5 \mathrm{Y}$ and $10 \mathrm{YR}$. The color codes with Value $\geqslant 6$ and Chroma $\geqslant 4$ were defined as colors of healthy sponges. All other color codes were ascribed to infected or rotten sponges. The area of the sponge 
covered by white or grey bacterial layers was recorded and expressed as a percentage of the total surface of the sponge. To compare all experiments, (1) the maximal bacterial cover, (2) the percentage of the sponge remaining healthy at the end of the experiment, and (3) the bacterial development rate were calculated. The bacterial development rate $\left(\% \mathrm{~d}^{-1}\right)$ is defined as the increase in bacterial cover per day up to the point of half-maximal cover.

To isolate the bacteria some material was taken from the sponges' surface, and spread on agar plates. Isolation media consisted of either: (1) $20 \mathrm{~g} \mathrm{l}^{-1}$ proteose peptone, $2 \mathrm{~g} \mathrm{l}^{-1}$ glucose, $30 \mathrm{mg} \mathrm{l}{ }^{-1} \mathrm{~K}_{2} \mathrm{TeO}_{3}, 25 \mathrm{~g} \mathrm{l}^{-1}$ $\mathrm{NaCl}$ and $12 \mathrm{~g} \mathrm{l}^{-1}$ agar ( $\mathrm{pH}$ 7.2); or (2) $30 \mathrm{~g} \mathrm{l}^{-1}$ sucrose, $3 \mathrm{~g} \mathrm{l}^{-1} \mathrm{NaNO}_{3}, 0.3 \mathrm{~g} \mathrm{l}^{-1} \mathrm{MgSO}_{4}, 1 \mathrm{~g} \mathrm{l}^{-1} \mathrm{KH}_{2} \mathrm{PO}_{4}, 0.1 \mathrm{~g}$ $1^{-1} \mathrm{KCl}_{1} 25 \mathrm{~g} \mathrm{l}^{-1} \mathrm{NaCl}$ and $12 \mathrm{~g} \mathrm{l}^{-1}$ agar $(\mathrm{pH} \mathrm{7.2)}$. The media were steam sterilized at $120{ }^{\circ} \mathrm{C}$ for $20 \mathrm{~min}$. Identification methods were as described in Holt \& Krieg (1984) and Lennette et al. (1980). To show whether the isolated bacteria were the primary infectors some carefully rinsed sponges were inoculated with these bacteria. This experiment was carried out at $23^{\circ} \mathrm{C}$ in continuously aerated sterile bottles with $300 \mathrm{ml}$ sterile seawater.

\section{RESULTS}

Healthy sponges were yellow or olive-yellow. A darkening of the sponge, often succeeded by the appearance of white or grey layers on its top, indicated bacterial growth. After a bacterial infection the sponge became black.

From the dark primary infection of the sponge the bacterium Alcaligenes faecalis was isolated, and from the white or grey layers the bacterium Acinetobacter calcoaceticus subsp. anitratis. Sponges cultured under conditions kept as sterile as possible, but infected with the isolated bacteria, showed a similar pattern of infection to those in the experiments with reduced waterflow rates, whereas the control showed hardly any infection (Table 1).

Table 1. Halichondrea panicea. Development of bacterial cover $(\%)$ on sponges cultured as sterile as possible, but infected with Alcaligenes faecalis (A.f.) and Acinetobacter calcoaceticus subsp. anitratis (A.c.)

\begin{tabular}{|lrrrr|}
\hline \multirow{2}{*}{ Infector } & \multicolumn{4}{c|}{ Bacterial cover after: } \\
& $1 \mathrm{~d}$ & $2 \mathrm{~d}$ & $3 \mathrm{~d}$ & $5 \mathrm{~d}$ \\
\hline None (control) & 0 & 0 & 5 & 10 \\
A.f. & 5 & 25 & 100 & 100 \\
A.c. & 0 & 5 & 25 & 100 \\
A.f. and A.C. & 5 & 10 & 25 & 75 \\
\hline
\end{tabular}

The occurrence of bacteria depended strongly on the temperature and the water-flow rate (Fig. 1). Higher temperatures and lower flow rates promoted the growth of bacteria and the bacterial coverage. The bacterial cover disappeared after reaching its maximum, leaving a patch of black rotten sponge tissue

The results were itemized in classes to present an overall picture (Fig. 2). Both the bacterial development rate and the maximal bacterial cover increased significantly with increasing temperature and decreasing water-flow rate. Sponges for the greater part infected could not recover as can be seen from the percentage of healthy sponge remaining at the end of an experiment in relation to the maximal bacterial cover (Fig. 3). When the maximal bacterial cover exceeded $70 \%$, no part of the sponge survived.

\section{DISCUSSION}

Normally, the species composition of the associated bacterial community on the crumb-of-bread sponge Halichondria panicea reflects that of its surroundings (Richter 1985). The fast developing bacteria Alcaligenes faecalis and Acinetobacter calcoaceticus subsp. anitratis are common in marine sediments and waters (Brisou 1953, Holding \& Shewan 1974). Because of low concentrations of antimicrobial substances in $H$. panicea (Thompson et al. 1985), it is not surprising that these 2 common bacteria were found. However, these bacteria have never been reported to be infectious to sponges.

The temperature-dependent rate of development of the bacterial cover reflects a very frequently found relation between temperature and bacterial activity (Oppenheimer 1970). The influence of water-flow rate on bacterial development in sponges may be more indirect. As a result of a reduced water-flow rate the removal of sponge exudates and excretion products on the top of the sponges is probably hampered. The internal ventilation of the sponge is partly effected by the beating of the flagella of the choanocyte cells; and partly by passive ventilation from the incurrent pores to the higher excurrent osculum, caused by velocity gradients in the water-flow near the sponge surface (Vogel \& Bretz 1972). The passive ventilation will decrease to the same degree when the water-flow is reduced. Thus the more the water-flow rate is reduced, the more bacterial substrate will accumulate inside as well as on the top of the sponge. This explains the observed higher development rates of bacteria at decreasing water-flow rates

Changes in the oxygen concentration probably did not occur during the experiments and, if any, were thought to have been of minor importance prior to the 
Low Water-flow rate - High

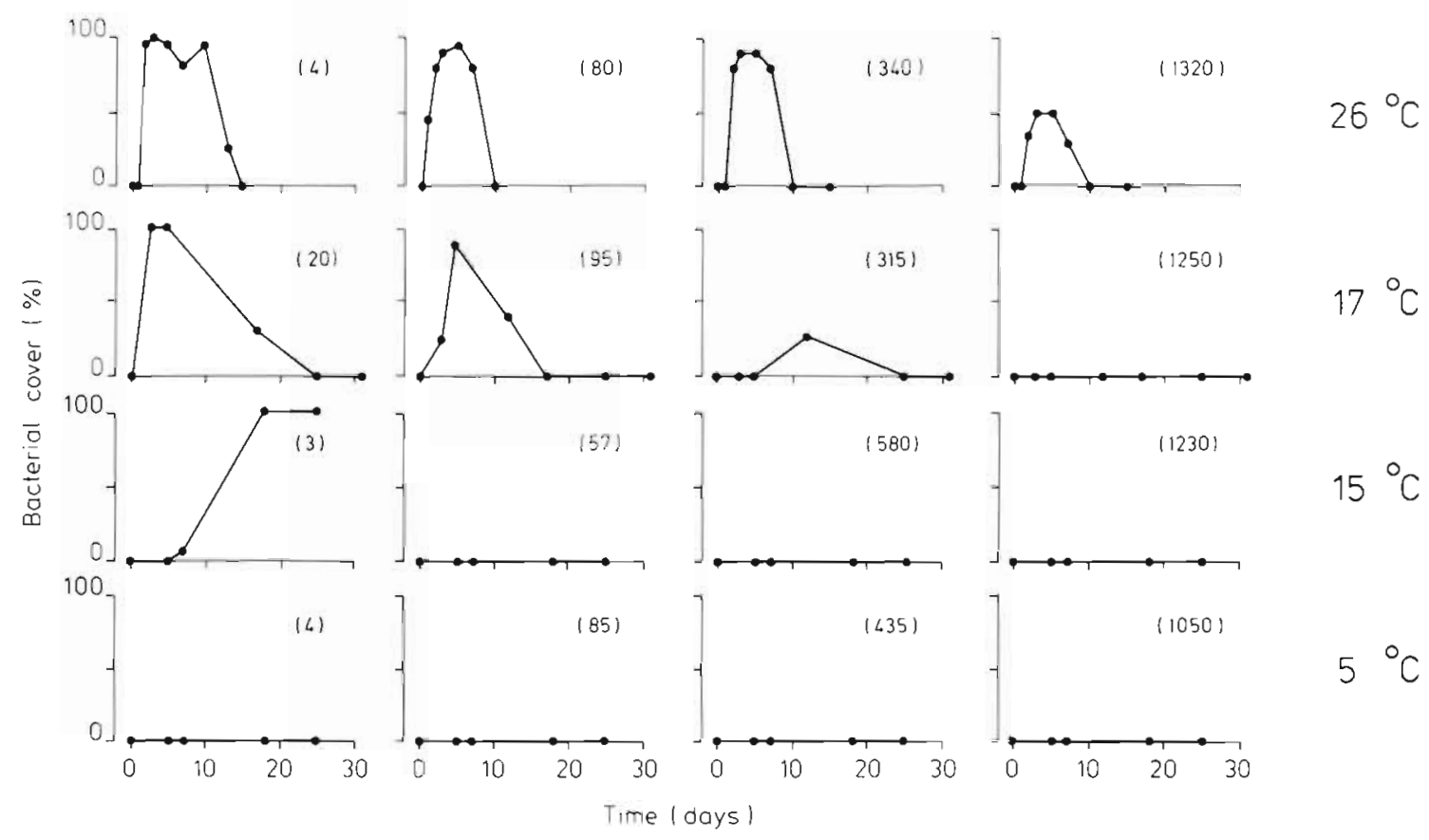

Fig. 1. Halichondria panicea. Changes in bacterial cover of crumb-of-bread sponge during experiments with lowered water-flow rates. Water-flow rates (in $\mathrm{ml} \mathrm{min}^{-1}$ ) are indicated in brackets

(a)

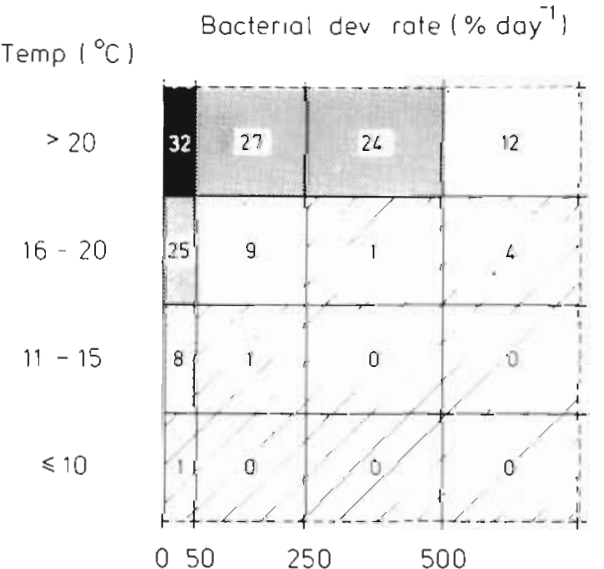

(b)

Max bacterial cover $(\%)$

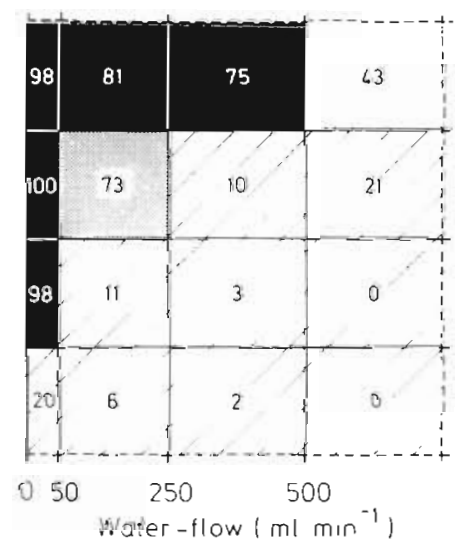

(a) (b)

$\square>30 \quad 75-100$

$15-30 \quad 50-75$

$7.5-15 \quad 25-50$

$0-7.5 \quad 0-25$

$\%$ day $^{-1} \%$

Fig. 2. Halichondria panicea. (a) Development rate and (b) maximal cover of bacteria on the crumb-of-bread sponge in relation to temperature and water-flow rate. Influence of temperature and water-flow rate are significant (Chi-square test on averages [a:

$p<0.01 ; b: p<0.001]$ and 2 -way variance analysis on arc-sin transformed ranges of each class $[a: p<0.05 ; b: p<0.10]$ )

initiation of bacterial growth on the sponges, because Acinetobacter calcoaceticus subsp. anitratus is an aerobic bacterium.

A maximal bacterial cover below $100 \%$ (Fig. 1) indicates a differential effect of reduced flow rates on parts of the sponge population. This might be caused by the irregular shape of the sponge. The deeper and more protected parts of the sponge will experience lower water-flow rates than the more exposed parts. Due to the lower water-flow rates the more protected parts can be overgrown by bacteria, whereas the more exposed parts remain healthy.

From our results it can be concluded that bacteriainduced mortality among the crumb-of-bread sponge 


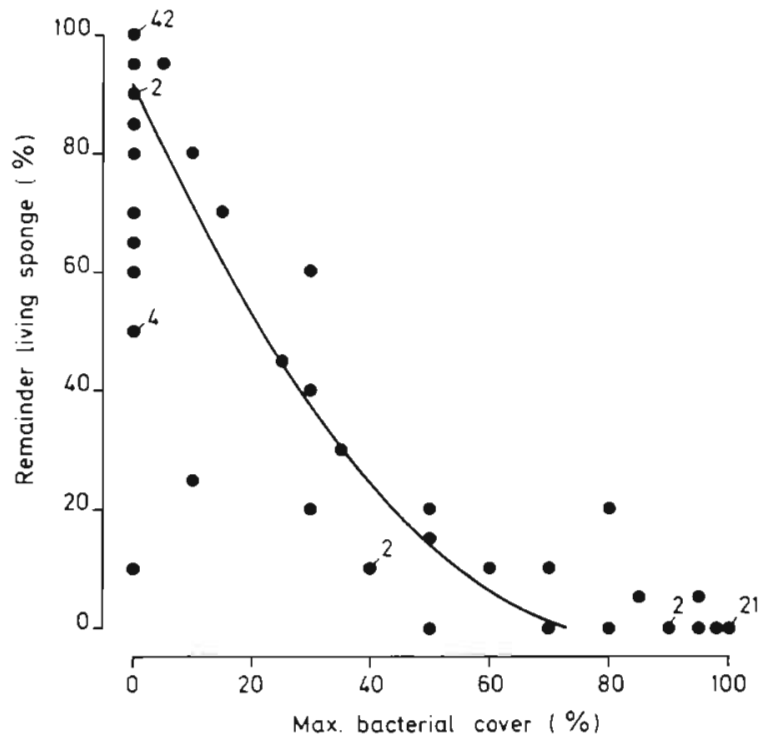

Fig. 3. Halichondria panicea. Relation between maximal bacterial cover of sponges and remainder of living sponge at the end of the experiments. The best-fitting line has been drawn (2nd-degree polynomial, $r=0.98, p<0.001$ ). Numbers of identical results are shown

Halichondrea panicea will hardly occur under normal field conditions with water-flow rates of up to $100 \mathrm{~cm}$ $\mathrm{s}^{-1}$ (comparable with $26000 \mathrm{ml} \mathrm{min}^{-1}$ in our experiments). At any temperature the bacterial development rate and the removal of bacteria and excretion products by passive and active ventilation currents in the sponge are in balance. However, if water-flow rates are strongly reduced, as for example during closure of a storm-surge barrier, bacteria can grow excessively on the excretion products of the sponges. Bacteria grow faster at higher temperatures and, therefore, the passive and active currents in the sponge have then to be higher to keep the sponge surface free from bacteria. This means that at higher temperatures the sponges will be overgrown by bacteria at higher water-flow rates.
Acknowledgements. Thanks are due to Drs A. W Fortuin, R. $H$. D. Lambeck and $W$. Zurburg for critically reading earlier drafts of this paper and to Dr A. G. Vlasblom for help in statistical analysis. The assistance of the 'Rijksinstituut voor Volksgezondheid en Milieuhygiene' in identifying the bacteria is greatly appreciated.

\section{LITERATURE CITED}

Arndt, W (1928). Porifera, Schwämme, Spongien. In: Dahl, F. (ed.) Die Tierwelt Deutschlands, 4. Teil. Gustav Fischer Verlag, Jena, p. 1-94

Brisou, J. (1953). Contribution à l'étude de la systématique des Pseudomonadaceae. Annls Inst. Pasteur (Paris) 93: $397-404$

Holding, A. J., Shewan, J. M. (1974). Genera of uncertain affiliation. In: Buchanan, R. E., Gibbons, N. E. (eds.) Bergey's manual of determinative bacteriology, Vol. VIII. Williams and Wilkins Co., Baltimore, p. 273-274

Holt, J. G., Krieg, N. R. (1984). Bergey's manual of systematic bacteriology, Vol. I. Williams and Wilkins Co., Baltimore

Lennette, E. H., Balous, A., Hausler, W. H., Truant, J. P. (1980). Manual of clinical microbiology. American Society for Microbiology, Washington

Lauckner, G. (1980). Diseases of Porifera. In: Kinne, O. (ed.) Diseases of marine animals, Vol. I, General aspects, Protozoa to Gastropoda. Wiley, Chichester, p. 139-165

Oppenheimer, C. H. (1970). Temperature, bacteria, fungi and blue-green algae. In: Kinne, O. (ed.) Marine ecology, Vol. I. Environmental factors, Part 1. Wiley, London, p. 347-361

Peattie, M. E., Hoare, R. (1981). The sublittoral ecology of the Menai Strait. II. The sponge Halichondria panicea (Pallas) and its associated fauna. Estuar. coast. Shelf Sci. 13: 621-635

Richter, W. (1985). Marine Schwämme als Substrat für Traustochytriaceae (marine niedere Pilze). Veröft. Inst. Meeresforsch. Bremerhaven 20: 141-149

Smies, M., Huiskies, A. H. L. (1981). Holland's eastern Scheldt estuary barrier scheme: some ecological considerations. Ambio 10: 158-165

Thompson, J. E., Walker, R. P., Faulkner, D. J. (1985). Screening and bioassays for biologically-active substances from forty marine sponge species from San Diego, California, USA. Mar. Biol. 88: 11-21

Vogel, S., Bretz, W. (1972). Inferfacial organisms: passive ventilation in the velocity gradients near surface. Science 157: $210-211$ 